Volume. 2 Nomor. 2

Periode: Juli - Desember 2018; hal. 66-81

p-ISSN : 2580-1112; e-ISSN : 2655-6669

Copyrighr@2018

Penulis memiliki hak cipta atas artikel ini

Jurnal Ilmiah Keperawatan Orthopedi (JIKO)

journal homepage:

https://ejournal.akperfatmawati.ac.id

\title{
Pengukuran Kinerja Perawat Wanita Dalam Penerapan Standar Asuhan Keperawatan Ruang Rawat Inap di Rumah Sakit Umum Fastabiq Sehat PKU Muhamadiyah
}

\author{
Nur Cahyani Ari Lestari ${ }^{1}$ \\ Akademi Kebidanan Abdi Persada Banjarmasin, Kalimantan Selatan
}

\begin{abstract}
Abstrak
Perawat sebagai garda terdepan dalam pelayanan kesehatan, tidak hanya dituntut untuk menunjukkan kemampuan dan profesionalitasnya semata dalam melaksanakan semua tindakan medis keperawatan.Tujuan penelitian untuk mengetahui pengaruh langsung dan tidak langsung beban kerja, konflik peran ganda, stres kerja, dan motivasi kerja terhadap kinerja perawat wanita dalam penerapan standar asuhan keperawatan ruang rawat inap di RSU Fastabiq Sehat PKU Muhamadiyah Pati tahun 2018. Jenis penelitian kuantitatif, desain penelitian crosssectional. dilakukan bulan Februari 2018 kepada Perawat wanita diruang rawat inap yang sudah menikah di RSU Fastabiq Sehat PKU Muhamadiyah berjumlah 86 orang menggunakan kuesioner. Persentase pengaruh langsung dan tidak langsung semua variabel terhadap kinerja perawat dalam model ini sebesar $90,51 \%$, diantaranya pengaruh langsung semua variabel terhadap kinerja dalam model sebesar $83,07 \%$, dan pengaruh tidak langsung sebesar 7,44\%. Model mampu menjelaskan variabilitas data sebesar $97,1 \%$, sedangkan $2,9 \%$ dijelaskan oleh variabel lain yang tidak dikaji dalam penelitian ini. Saran dari penelitian ini Diharapkan perawat Rumah Sakit Umum Fastabiq Sehat PKU Muhamadiyah Daerah Pati menciptakan kondisi kerja yang nyaman sehingga dapat menghindari untuk terjadinya konflik dalam bekerja.
\end{abstract}

Kata Kunci : Kinerja, Beban Kerja, Konflik, Stres, Motivasi

\begin{abstract}
Nurses as the front guard in health services, not only required to demonstrate the ability and professionalism solely in carrying out all the medical actions nursing. The purpose of this research was to know the direct and indirect effect of workload, dual role conflict, work stress, and work motivation on the performance of female nurses in the application of nursing care standards in the depth of the hospital in dept. RSU Fastabiq Sehat PKU Muhamadiyah base of Pati in 2018. Quantitative research type, Sectional. conducted in February 2018 to nurse woman in marriage hospitalized room at depati Fastabiq Sehat PKU Muhamadiyah hospital of base of Pati counted 86 people using questioner. The percentage of direct and indirect influence of all variables on the nurse's performance in this model is $90.51 \%$, including the direct influence of all the variables on the performance in the models $83.07 \%$, and the indirect effect of $7.44 \%$. The model is able to explain the data variability of $97.1 \%$, while $2.9 \%$ is explained by other variables not
\end{abstract}

1 e-mail: nurcahyani_arilestari@yahoo.com 
studied in this study. Suggestion from this research It is expected that the nurse of Pati General Hospital creates a comfortable working condition so as to avoid of conflict in the work.

Keywords : Performance, Workload, Conflict, Stress, Motivation

\section{Pendahuluan}

Sumber daya manusia atau tenaga kerja adalah unsur terpenting dalam institusi rumah sakit. Jika kinerja perawat rendah, maka dapat dipastikan mutu pengelolaan dan pelayanan rumah sakitnya juga rendah. Dalam upaya meningkatkan mutu pelayanan di rumah sakit, diperlukan dukungan sumber daya manusia khususnya perawat, yang mampu mengemban tugas dan terus mengadakan perubahan.

Perawat sebagai garda terdepan dalam pelayanan kesehatan, tidak hanya dituntut untuk menunjukkan kemampuan dan juga profesionalitasnya semata dalam melaksanakan semua tindakan medis keperawatan. Seorang perawat juga diharapkan memiliki sensitivitas emosional dalam menghadapi semua pasien yang ditanganinya dengan berbagai situasi dan kondisi psikologis. ${ }^{1}$

$2016 \begin{gathered}\text { Laporan Pembangunan Manusia } \\ \text { yang dikeluarkan UNDP }\end{gathered}$ menunjukan bahwa IPM Indonesia dibidang kinerja petugas kesehatan tahun 2016 di urutan 124 dari 187 negara yang disurvei dengan skor 0,617.

Peringkat ini turun dari peringkat 108 pada tahun 2015. Ditingkat ASEAN Singapura berada di peringkat 26, Brunei Darussalam 33, sementara yang berada di bawah Indonesia untuk negara ASEAN adalah Vietnam 128, Timor Leste 147, dan negara Myanmar 149.

Kinerja keperawatan merupakan tolak ukur mutu pelayanan rumah sakit secaraumum. Perawat sebagai pemberi jasa merupakan ujung tombak pelayanan di rumah sakit, karena perawat berada 24 jam dalam memberikan asuhan keperawatan. Tanggung jawab yang demikian beratnya kadang belum di tunjang oleh sumber daya manusia yang memadai sehingga kinerja perawat menjadi sorotan baik oleh profesi lain maupun pasien atau keluarganya. ${ }^{2}$

Profesionalisme perawat dalam bekerja dapat dilihat dari Standar Asuhan Keperawatan (SAK) yang diberikan kepada klien yang dirawatnya. Perawat perlu mendokumentasikan segala bentuk asuhan keperawatan yang diberikan melalui pencatatan atau pendokumentasian. Hal ini dilakukan sebagai bentuk tanggung jawab dan tanggung gugat perawat terhadap klien yang dirawatnya.

Oleh karena itu pelaksanaan asuhan keperawatan merupakan salah satu tolak ukur kualitas pelayanan dari suatu rumah sakit. Hal inilah yang masih memerlukanperhatian bagi para pelaksana asuhan keperawatan. Oleh karenanya perawat yang dapat melaksanakan asuhan keperawatan sesuai standar asuhan mempunyai arti yang sangat penting dalam upaya peningkatan mutu pelayanan. Kualitas kerja perawat menentukan mutu pelayanan rumah sakit sedangkan pendokumentasian SAK merupakan indikator dari mutu pelayanan rumah sakit. $^{3}$

Kinerja perawat dalam SAK dapat mempengaruhi mutu pelayanan kesehatan. Studi oleh Direktorat Keperawatan dan Keteknisian Medik Kementrian Kesehatan RI bekerjasama dengan WHO tahun 2015 di 4 provinsi di Indonesia, yaitu Jakarta, Sumatera Utara, Sulawesi Utara dan Kalimantan Timur, menemukan 47,4 persen perawat belum memiliki uraian tugas secara tertulis, $70,9 \%$ perawat tidak pernah mengikuti pelatihan dalam 3 tahun terakhir, 39,8\% perawat masih melaksanakan tugas non keperawatan, serta belum dikembangkan sistem monitoring dan evaluasi kinerja perawat. 
Sedangkan menurut Kemenkes Tahun 2016, Pendokumentasian SAK di provinsi Jawa Tengah masih belum sesuai dengan yang ditetapkan oleh Depkes yaitu persentase cakupan Standar Asuhan Keperawatan (SAK) baik dirumah sakit maupun di puskesmas rawat inap adalah sebesar $80 \%$.

Kinerja merupakan hasil atau prestasi kerja yang dinilai dari segi kualitas maupun dari segi kuantitas berdasarkan standar kerja yang dapat ditentukan oleh pihak organisasi. kinerja yang baik adalah kinerja yang optimal, yaitu kinerja yang sesuai standar organisasi dan mendukung tercapainya tujuan organisasi. ${ }^{4}$

Faktor lain yang mempengaruhi kinerja perawat adalah beban kerja perawat yang berlebihan. Fluktuasi beban kerja merupakan bentuk lain dari penyebab timbulnya stres kerja. Untuk jangka waktu tertentu bebannya sangat ringan dan saat-saat lain bebannya bisa berlebihan. Situasi tersebut dapat kita jumpai pada perawat yang bekerja di rumah sakit. Keadaan tersebut dapat menimbulkan kecemasan ketidakpuasan kerja dan kecenderungan meninggalkan pekerjaan. $^{5}$

Terdapat pengaruh yang positif dan signifikan konflik pekerjaankeluarga, konflik keluarga-pekerjaan dan stress kerja memiliki pengaruh yang negatif terhadap kinerja perawat. Hal ini menunjukan bahwa semakin besar konflik peran dan stress kerja maka kinerja perawat akan semakin menurun,demikian pula sebaliknya. Oleh karena itu, untuk meningkatkan kinerja para perawat perlu diperhatikan faktorfaktor penyebab stress di antaranya konflik pekerjaan-keluarga dan konflik keluarga-pekerjaan. ${ }^{6}$

Pekerjaan seorang perawat sangatlah berat, dari satu sisi, seorang perawat harus menjalankan tugas yang menyangkut kelangsungan hidup pasien yang dirawat, disisilain keadaan psikologis perawat sendiri juga harus tetap terjaga, kondisi seperti inilah yang dapat menimbulkan rasa tertekan pada perawat. Sehingga dia mudah mengalami stres, stres merupakan ketegangan mental yang mengganggu kondisi emosional, proses berpikir dan kondisi fisik seseorang. ${ }^{7}$

Faktor lain yang dapat mempengaruhi kinerja perawat dalam pelayanan keperawatan di rumah sakit adalah motivasi kerja perawat. motivasi merupakan kesediaan mengeluarkan tingkat upaya tinggi ke arah tujuan organisasi yang dikondisikan oleh pengetahuan upaya itu untuk memenuhi kebutuhan individual. di lingkungan organisasinya.

Hal ini berarti bahwa dimana motivasi merupakan pendorong utama untuk timbulnya perilaku yang mengarah pada tujuan tertentu dengan penuh komitmen untuk mencapai suatu tujuan yang telah ditetapkan pada suatu organisasi ataupun disuatu perusahaan. ${ }^{8}$

Berdasarkan hasil studi pendahuluan wawancara yang dilakukan terhadap 10 orang perawat diperoleh temuan dimana sebanyak 6 perawat $(60 \%)$ mengaku belum menyelesaikan laporan asuhan keperawatan, sebanyak 6 orang $(60 \%)$ mengaku pekerjaan perawat cukup berat seperti melakukan asuhan keperawatan secara terus menerus, kompleksitas pekerjaan dan pembagian shif kerja malam yang harus di jalani perawat. sebanyak 5 orang (50\%) mengaku konflik peran ganda muncul karena konflik pekerjaan-keluarga, sebanyak 6 orang $(60 \%)$ mengalami stress, sebanyak 7 orang (70\%) perawat mengatakan pendokumentasian asuhan keperawatan tidak memberikan nilai tambah sehingga mereka tidak termotivasi untuk dapat menyelesaikan pendokumentasian, sedangkan sisanya yaitu 3 orang $(30 \%)$ tetap untuk mengerjakan pendokumentasian asuhan keperawatan dikarenakan merasa sudah menjadi tanggung jawabnya untuk melakukan pendokumentasian.

Tujuan penelitian ini adalah untuk mengetahui pengaruh langsung dan tidak 
langsung serta besarannya antara beban kerja, konflik peran ganda, stress kerja dan motivasi kerja terhadap kinerja perawat wanita dalam penerapan standar asuhan keperawatan di ruang rawat inap di RSU Fastabiq Sehat PKU Muhamadiyah tahun 2018.

\section{Metode Penelitian}

Penelitian ini dilakukan dengan menggunakan metode penelitian kuantitatif dengan desain penelitian cross sectional dengan pendekatan kuantitatif. Penelitian ini dilakukan untuk mempelajari dinamika korelasi antara variabel eksogen (variabel bebas) dengan variabel endogen (variabel terikat). ${ }^{9}$

Penelitian ini dilakukan dalam kurun waktu yang bersamaan untuk mengetahui pengaruh langsung dan tidak langsung serta besarannya antara beban kerja, konflik peran ganda, stress kerja dan motivasi kerja terhadap kinerja perawat wanita dalam penerapan standar asuhan keperawatan di ruang rawat inap di RSU Fastabiq Sehat PKU Muhamadiyah tahun 2018.

Populasi adalah subyek yang hendak diteliti dan yang memiliki sifatsifat yang sama. ${ }^{10}$ Populasi dalam penelitian ini yaitu seluruh perawat wanita diruang rawat inap yang bekerja di RSU Fastabiq Sehat PKU Muhamadiyah sebanyak 98 orang perawat. Sedangkan Sampel yang diambil dalam penelitian, 86 orang perawat dari setiap ruangan, ruangan yang diteliti ada 6 ruangan yaitu ruangan penyakit dalam, neonatal, perawatan luka bakar, anak, bedah dan ICU.

Sesuai dengan alat analisis yang digunakan yaitu SEM, maka penemuan jumlah sampe representative yaitu jumlah indikator dikalikan 5 sampai 10 indikator yang akan diestimasi. Karena jumlah indikator dalam penelitian ini adalah 14 maka jumlah sampelnya berada pada rentang 70-140. Berdasarkan kedua pertimbangan tersebut maka ukuran sampel dalam penelitian ini ditetapkan 86 responden. ${ }^{11}$
Kriteria inklusi dan eksklusi sampel penelitian ini adalah : (1) kriteria inklusi yaitu, Perawat wanita yang bertugas di rawat inap saat penelitian dan sudah menikah dan sehat jasmani rohani. (2) kriteria eksklusi yaitu, subjek penelitian yang karena suatu sebab tertentu dikeluarkan dari kriteria inklusi. 12

Penelitian ini menggunakan alat bantu (instrument) berupa angket yang mengandung masing-masing terdiri indikator dalam 5 item pertanyaan. Cara pengumpulan data primer yang digunakan dalam penelitian ini diperoleh peneliti terhadap responden yang telah sesuai dengan kriteria yang ditetapkan langsung terhadap kinerja perawat dalam SAK Bentuk pertanyaan adalah dengan kuesioner tertutup dimana daftar pertanyaan yang akan ditanyakan langsung kepada responden (obyek penelitian).

$\begin{array}{rr} & \text { Pertanyaan-pertanyaan dibuat } \\ \text { dengan menggunakan skala }\end{array}$
semantik(Semantic Deferensial) dan skala likert.Skala semantik digunakan untuk mengukur persepsi dan pendapat responden dengan cara memberi urutan kuantitatif terhadap subjek penelitian. Sedangkan skala likert untuk mengukur baik tanggapan positif maupun negatif. 13 .

Sebelumnya akan peneliti meminta persetujuan dari sampel terpilih untuk bersedia menjadi responden dalam penelitian ini. Disamping itu dilakukan pula pengumpulan data primer dan sekunder. Data primer seperti diperoleh dengan penyebaran angket yang dibuat peneliti.

Analisis univariat yang dilakukan adalah untuk mengetahui karakteristik dari masing-masing variabel endogen dan eksogen untuk mengetahui gambaran distribusi dan tiap-tiap variabel yang diteliti. $^{14}$ analisa ini digunakan untuk mendapat mendiskripsikan variabel dengan cara membuat tabel distribusi frekuensi dan dihitungan persentase. 
Analisis dilakukan dengan menggunakan SEM dengan Pertial Least Square (PLS), adapun langkahlangkahnya sebagai berikut : (a) merancang Model Struktural (Inner Model); (b) merancang Model Pengukuran (Outer Model); (c) Goodness Of Fit; (d) pengujian hipotesis. Suatu indikator reflektif dinyatakan valid jika mempunyai loading factordi atas 0,5 terhadap konstruk yang dituju berdasarkan pada subtantive contet-nya dengan melihat signifikansi dari weight $(\mathrm{t}=1,96)$.

Hasil evaluasi signifikan inner modeldiatur dalam output SmartPLS 2.0 di bawah ini dengan mengevaluasi refleksi nilai T-Statistic indikator terhadap variabelnya. ${ }^{15}$

Berdasarkan dari Gambar 2 menyatakan nilai T-Statistik direfleksikan terhadap variabelnya sebagian besar > 1,96, sehingga menunjukkan blok indikator berpengaruh positif dan signifikan untuk merefleksikan variabelnya.

\section{Hasil Penelitian}

Hasil penelitian ini disusun berdasarkan sistematika yang diambil dengan gambaran analisis univariat yang bertujuan untuk melihat distribusi frekuensi variabel dependen dan independen. Analisa bivariat untuk melihat pengaruh antara variabel eksogen dan variabel endogen. Kemudian diakhir penelitian ini diberikan gambaran analisis SEM untuk menjelaskan hubungan yang komplek dari beberapa variabel yang diuji dalam penelitian ini.

Responden dalam penelitian ini adalah perawat wanita yang bertugas diruang rawat inap. Penyebaran kuesioner disertai dengan identitas responden. Dari 86 responden menunjukkan bahwa sebagian besar perawat berumur pada rentang 26-30 tahun sebanyak 42 responden $(48,8 \%)$. Berdasarkan pendidikan memperlihatkan bahwa sebagian besar adalah profesi Ners sebanyak 42 responden $(48,8 \%)$.
Sedangkan untuk berdasarkan masa kerja pada rentang kerja >3-5 tahun sebanyak 79 responden $(91.9 \%)$.

Data responden juga dapat dinyatakan dalam beberapa kategori disertai dengan perhitungan range (kisaran), mean (rata-rata), dan standar deviasi (penyimpangan).

Pada variabel kinerja perawat, jawaban responden berada antara 59-122 mendekati kisaran teoritisnya 25-125 dengan nilai rata-rata 106,80 dan standar deviasi 11,88. Data tersebut memberikan gambaran bahwa kinerja perawat cenderung baik.

Pada variabel beban kerja, jawaban responden berada antara 33-74 mendekati kisaran teoritisnya 15-75 dengan nilai rata-rata 63,36 dan standar deviasi 8,79. Data tersebut memberikan gambaran bahwa beban kerja cenderung tinggi.

Pada variabel konflik peran ganda, jawaban responden berada antara 15-56 mendekati kisaran teoritisnya 15 75 dengan nilai rata-rata 47,82 dan standar deviasi 7,80.

Data tersebut memberikan gambaran bahwa konflik peran ganda cenderung menurun.Pada variabel stres kerja, jawaban responden berada antara 16-57 mendekati kisaran teoritisnya 1575 dengan nilai rata-rata 47,45 dan standar deviasi 8,80.

Data tersebut memberikan gambaran bahwa stres kerja cenderung menurun. Pada variabel motivasi kerja, jawaban responden berada antara 39-73 mendekati kisaran teoritisnya 15-75 dengan nilai rata-rata 64,45 dan standar deviasi 6,86. Data tersebut memberikan gambaran motivasi kerja cenderung baik.

Diketahui bahwa deskripsi jawaban 86 responden tentang variabel kinerja sebagian besar berada pada rentang aktual 104-112 (58,1 \%), pada variabel beban kerja sebagian besar berada pada rentang aktual 6368(48,8\%), pada variabel Konflik Peran Ganda sebagian besar berada pada rentang aktual 21-26 (44,2\%), pada 
variabel stres kerja sebagian besar berada pada rentang aktual 16-21 $(38,4 \%)$ dan pada variabel Motivasi kerja sebagian besar berada pada rentang aktual 64-68 (44,2\%).

Variabel kinerja perawat dalam penelitian ini diukur melalui 25 butir pertanyaan dengan penilaian 1-5. Sehingga skor kuesioner berkisar antara 25-125 dan skor aktual berkisar antara 104-122. Variabel beban kerja dalam penelitian ini diukur melalui 15 butir pertanyaan dengan penilaian 1-5. Sehingga skor kuesioner berkisar antara 15-75 dan skor aktual berkisar antara 6368.

Variabel konflik peran ganda dalam penelitian ini diukur melalui 15 butir pertanyaan dengan penilaian 1-5. Sehingga skor kuesioner berkisar antara 15-75 dan skor aktual berkisar antara 2126. Variabel stres kerja dalam penelitian ini diukur melalui 15 butir pertanyaan dengan penilaian 1-5. Sehingga skor kuesioner berkisar antara 15-75 dan skor aktual berkisar antara 16-21. Variabel motivasi kerja dalam penelitian ini diukur melalui 15 butir pertanyaan dengan penilaian 1-5. Sehingga skor kuesioner berkisar antara 15-75 dan skor aktual berkisar antara 64-68.

Uji chi-suare dilakukan untuk melihat variasi total jawaban responden pervariabel terhadap karakteristik penelitian. Berdasarkan hasil uji chisuarediketahui $P$-value $\alpha=5 \%$ (Asymp. $\mathrm{Sig}$ ) untuk setiap karakteristik responden lebih besar dari 0,05. Hasil uji tersebut membuktikan bahwa karakteristik uji chisquare dilakukan untuk melihat variasi total jawaban responden pervariabel terhadap karakteristik penelitian. Berdasarkan hasil uji chi-suare diketahui $P$-value $\alpha=5 \%$ (Asymp. Sig) untuk setiap karakteristik responden lebih besar dari 0,05. Hasil uji tersebut membuktikan bahwa karakteristik responden tidak ada hubungan terhadap variasi jawaban dari variabel kinerja perawat.

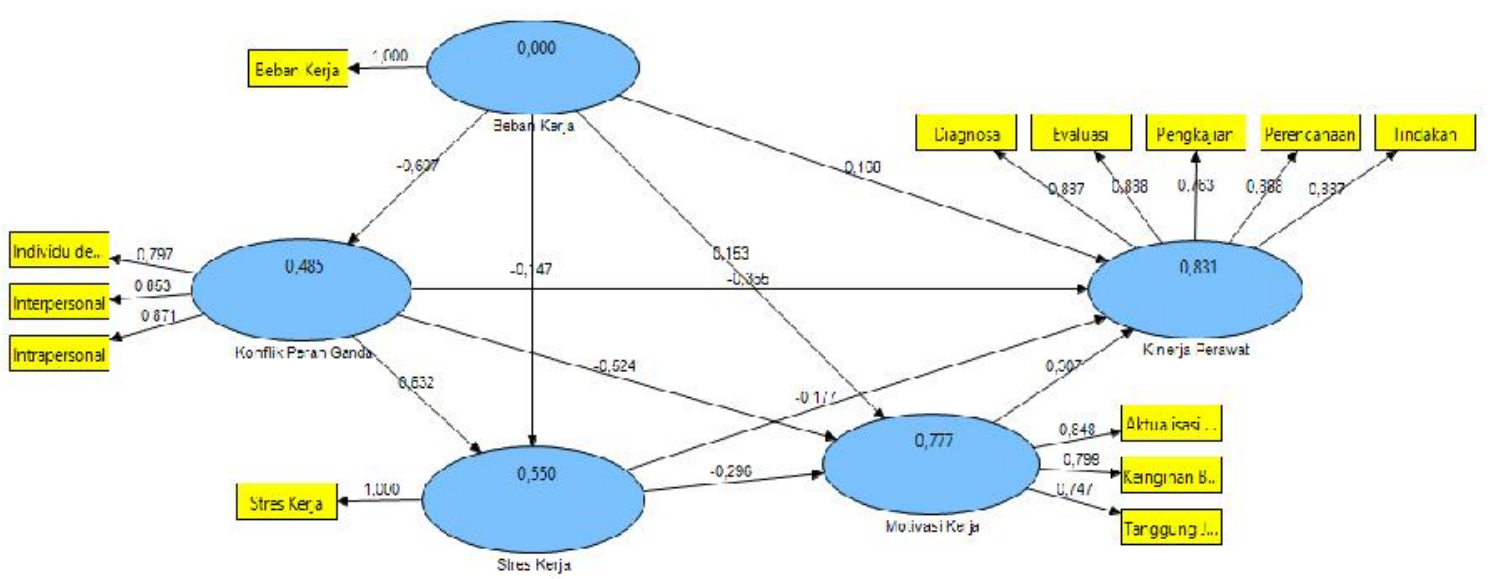

Gambar 1. Output PLS (Loading Factors)

Berdasarkan hasil uji chisuarediketahui $P$-value $\alpha=5 \%$ (Asymp. $S i g)$ untuk setiap karakteristik responden lebih besar dari 0,05. Hasil uji tersebut membuktikan bahwa karakteristik responden tidak ada hubungan terhadap 
variasi jawaban dari variabel beban kerja.

Berdasarkan hasil uji chi-suare diketahui $p$-value $\alpha=5 \%$ (Asymp. Sig) untuk setiap karakteristik responden lebih besar dari 0,05. Hasil uji tersebut membuktikan bahwa karakteristik responden tidak ada hubungan terhadap variasi jawaban dari variabel konflik peran ganda.

Berdasarkan hasil uji chi-suqare diketahui $p$-value $\alpha=5 \%$ (Asymp. Sig) untuk setiap karakteristik responden lebih besar dari 0,05. Hasil uji tersebut membuktikan bahwa karakteristik responden tidak ada hubungan terhadap variasi jawaban dari variabel stres kerja.

Berdasarkan hasil uji chisuarediketahui $p$-value $\alpha=5 \%$ (Asymp. Sig) untuk setiap karakteristik responden lebih besar dari 0,05. Hasil uji tersebut membuktikan bahwa karakteristik responden tidak ada hubungan terhadap variasi jawaban dari variabel motivasi kerja. nilai loading factor telah memenuhi persyaratan yaitu nilai loading faktor lebih besar dari 0,5 .

Berdasarkan dari gambar 1 terlihat bahwa nilai faktor loading telah memenuhi persyaratan yaitu nilai loading factor lebih besar dari 0,5. Suatu indikator dinyatakan valid jika mempunyai loading factor tertinggi kepada konstruk yang dituju dibandingkan loading factor kepada konstruk lain.

Berdasarkan tabel dibawah menunjukkan bahwa korelasi konstruk lebih besar dari konstruk lainnya. Hal ini menunjukkan bahwa konstruk laten memprediksi ukuran pada bloknya lebih baik dari pada ukuran pada blok lainnya.

Hasil analisis pengelolaan data terlihat bahwa konstruk yang digunakan untuk membentuk sebuah model penelitian pada pada proses analisis faktor konfirmatori telah memenuhi kriteria goodnessof fityang telah ditetapkan. Nilai probabilitypada analisis ini menunjukkan nilai diatas signifikan yaitu 0,5 .

Dari hasil pengolahan data diatas juga dapat dilihat bahwa setiap indikator atau dimensi pembentuk variabel laten menunjukkan hasil yang baik, yaitu dengan nilai loading factoryang tinggi dimana masing-masing indikator lebih besar dari 0,5.

Dengan hasil ini, maka dapat dikatakan bahwa indikator pembentuk variabel kinerja, beban kerja, konflik peran ganda, stres kerja dan motivasi kerja dikatakan baik atau valid. Cara lain untuk menguji discriminant validityyaitu melalui square root of average variance extraced(AVE).

Direkomendasikan nilai AVE harus lebih besar dari 0,50. Berikut nilai AVE pada Tabel 1. Berdasarkan tabel 1 semua variabel dinyatakan valid karena memberikan nilai AVE diatas 0,50. Sehingga dapat disimpulkan bahwa dicriminantvalidity yang baik atau valid. Metode lain untuk menilai discriminant validity adalah membandingkan nilai square root of average variance extraced(AVE).

Tabel 1. Nilai AVE dan akar AVE

\begin{tabular}{l|c|c|c}
\hline \multicolumn{2}{c|}{ Hasil Uji } & & \multirow{2}{c}{ Kriteria Uji >0,5 } \\
\hline Beban Kerja & $\boldsymbol{A} \boldsymbol{V E}$ & Akar $\boldsymbol{A} \boldsymbol{V} \boldsymbol{E}$ & \\
Kinerja Perawat & 1,000 & 1,000 & Valid \\
Konflik Peran ganda & 0,746 & 0,864 & Valid \\
Motivasi kerja & 0,638 & 0,841 & Valid \\
Stres Kerja & 1,000 & 1,000 & Valid \\
\hline
\end{tabular}

Sumber : Smartpls 2.0 diolah tahun 2017

Goodness-fit model. Berikut adalah hasil pengukuran $r$-square yang juga merupakan nilai Goodness-fit model. Setelah dilakukan bootstrapping 
untuk mengukur nilai $T$-statistic dari masing-masing konstruk laten terhadap konstruknya, maka nilai T-statistic dibandingkan dengan nilai $\alpha=0,05(1,96)$.

Ketentuannya, apabila nilai $t$ statistic lebih besar dari nilai $\alpha=0,05$ $(1,96)$, maka konstruk laten tersebut signifikan terhadap konstruknya. Inner model disebut juga dengan model struktural dapat dievaluasi dengan melihat uji nilai $R$-square, uji hipotesis $T$-statistic, pengaruh variabel langsung dan prediktif.

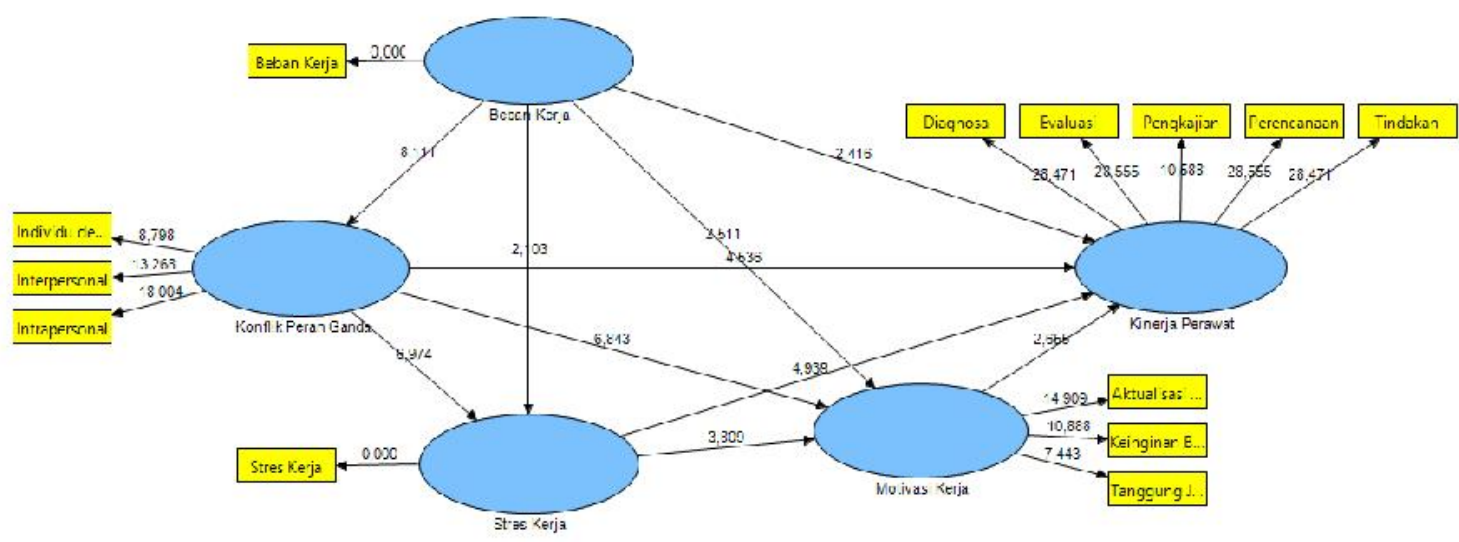

Gambar 2. Output PLS (T-Statistic)

Nilai $q$-square berfungsi untuk menilai besaran keragaman atau variasi data penelitian terhadap fenomena. Inner modeldisebut juga dengan model struktural dapat dievaluasi dengan melihat uji nilai $r$-square, hipotesis $t$ statistic, pengaruh variabel langsung dan tidak langsung serta $q$-square.

Selanjutnya dilakukan uji inner model, adalah model struktural dapat dievaluasi dengan melihat uji nilai $r$ square, uji hipotesis $t$-statistic, pengaruh variabel langsung dan prediktif (nilai $q$ square). pengujian ini terhadap model struktural dilakukan dengan melihat $r$ square yang merupakan uji yang sedang dikaji dan hasilnya pada tabel 2.

Tabel 2. Evaluasi Nilai $R$-Square

\begin{tabular}{l|c}
\multicolumn{1}{c|}{ Variabel } & $\boldsymbol{R}$ Square \\
\hline Beban Kerja & - \\
Kinerja Perawat & 0,830 \\
Konflik Peran Ganda & 0,485
\end{tabular}

\begin{tabular}{l|c}
\hline \multicolumn{1}{c|}{ Variabel } & $\boldsymbol{R}$ Square \\
\hline Motivasi Kerja & 0,776 \\
Stres Kerja & 0,550 \\
\hline
\end{tabular}

Sumber : Smartpls 2.0 diolah tahun 2017

Berdasarkan tabel 2 dapat dilihat bahwa nilai $r$-square menunjukkan bahwa model penelitian menjelaskan sekitar 48,51\% dari variabilitas Konflik peran ganda dapat dijelaskan oleh ketiga konstruk dan sisanya 51,49 \% dapat dijelaskan oleh variabel lain yang tidak dibahas dalam penelitian ini, sekitar $55,04 \%$ dari variabilitas Stres Kerja dapat dijelaskan oleh ketiga konstruk dan sisanya 44,96\% dapat dijelaskan oleh variabel lain yang tidak dibahas dalam penelitian ini, sekitar 77,67 \% dari variabilitas Motivasi kerja dapat dijelaskan oleh ketiga konstruk dan sisanya 22,33 \% dapat dijelaskan oleh variabel lain yang tidak dibahas dalam 
penelitian ini, dan sekitar 83,06\% dari variabilitas Kinerja Perawat dapat dijelaskan oleh kelima konstruk dan sisanya $16,94 \%$ dapat dijelaskan oleh variabel lain yang tidak dibahas dalam penelitian ini.

Nilai t-statistic direfleksikan terhadap variabelnya sebagian besar 1,96, sehingga menunjukkan blok indikator berpengaruh positif dan sinifikan untuk merefleksikan variabelnya. Untuk Variabel Beban Kerja berpengaruh positif terhadap Kinerja Perawat, hasil uji menunjukkan ada pengaruh 0,168, sedangkan nilai t-statistic sebesar 2,41dan signifikan pada $\alpha=5 \%$.

Nilai $t$-statistic tersebut berada di atas nilai kritis (1,96).Beban Kerja berpengaruh negatif terhadap Konflik peran ganda, hasil uji menunjukkan ada pengaruh-0,696, sedangkan nilai $t$ statistic sebesar 8,11dan signifikan pada $\alpha=5 \%$. Nilai $t$-statistic tersebut berada di atas nilai kritis $(1,96)$.

Beban Kerja berpengaruh positif terhadap Motivasi Kerja, hasil uji menunjukkan ada pengaruh 0,152, sedangkan nilai $t$-statistic sebesar 2,51 dan signifikan pada $\alpha=5 \%$. Nilai $t$ statistic tersebut berada di atas nilai kritis $(1,96)$. Beban Kerja berpengaruh negatif terhadap Stres Kerja, hasil uji menunjukkan ada pengaruh -0,146, sedangkan nilai t-statistic sebesar 2,10 dan signifikan pada $\alpha=5 \%$. Nilai $t$ statistic tersebut berada di atas nilai kritis $(1,96)$.

Konflik peran ganda berpengaruh negatif terhadap Kinerja Perawat, hasil uji menunjukkan ada pengaruh $-0,355$, sedangkan nilai $t$-statistic sebesar 4,53 dan signifikan pada $\alpha=5 \%$. Nilai $t$ statistic tersebut berada di atas nilai kritis $(1,96)$. Konflik peran ganda berpengaruh negatif terhadap Motivasi Kerja, hasil uji menunjukkan ada pengaruh $-0,523$, sedangkan nilai t-statistic sebesar 6,84 dan signifikan pada $\alpha=5 \%$. Nilai $t$ statistic tersebut berada di atas nilai kritis $(1,96)$.

Konflik peran ganda berpengaruh positif terhadap Stres kerja, hasil uji menunjukkan ada pengaruh 0,632, sedangkan nilai $t$-statistic sebesar 6,97 dan signifikan pada $\alpha=5 \%$. Nilai $t$ statistic tersebut berada di atas nilai kritis $(1,96)$.

Stres Kerja berpengaruh negatif terhadap Kinerja Perawat, hasil uji menunjukkan ada pengaruh 0,177, sedangkan nilai $t$-statistic sebesar 4,93 dan signifikan pada $\alpha=5 \%$. Nilai $t$ statistic tersebut berada di atas nilai kritis $(1,96)$. Stres kerja berpengaruh negatif terhadap Motivasi Kerja, hasil uji menunjukkan ada pengaruh 0,295, sedangkan nilai $t$-statistic sebesar 3,80 dan signifikan pada $\alpha=5 \%$. Nilai $t$ statistic tersebut berada di atas nilai kritis $(1,96)$.

Motivasi Kerja berpengaruh positif terhadap Kinerja Perawat, hasil uji menunjukkan ada pengaruh 0,307, sedangkan nilai $t$-statistic sebesar 2,65 dan signifikan pada $\alpha=5 \%$. Nilai $t$ statistic tersebut berada di atas nilai kritis $(1,96)$.

Berdasarkan tabel 3 menyatakan bahwa Beban Kerja berpengaruh secara langsung dan tidak langsung terhadap Kinerja Perawat. terdapat pengaruh langsung sebesar 12,31\%, untuk pengaruh tidak langsung antara Beban Kerja terhadap Kinerja Perawat melalui Konflik Peran ganda, Stres Kerja, Motivasi Kerja mendapat nilai sebesar 0,76\%. Konflik Peran Ganda berpengaruh secara langsung dan tidak langsung terhadap Kinerja perawat. 
Tabel 3. Pengaruh Langsung dan Tidak Langsung Kinerja Perawat Wanita Dalam Penerapan Standar Asuhan Keperawatan Rumah Sakit

\begin{tabular}{|c|c|c|c|c|c|c|c|}
\hline Sumber & $\begin{array}{c}L V \\
\text { Correlation }\end{array}$ & $\begin{array}{c}\text { Direct } \\
\text { Path }\end{array}$ & $\begin{array}{c}\text { Inderect } \\
\text { Path }\end{array}$ & Total & $\begin{array}{c}\text { Direct } \\
\%\end{array}$ & $\begin{array}{c}\text { Indirect } \\
\%\end{array}$ & $\begin{array}{c}\text { Total } \\
\%\end{array}$ \\
\hline $\begin{array}{l}\text { Beban } \\
\text { Kerja }\end{array}$ & 0,732 & 0,168 & 0,564 & 0,7318 & $12,31 \%$ & $0,76 \%$ & $13,07 \%$ \\
\hline $\begin{array}{l}\text { Konflik } \\
\text { Peran } \\
\text { Ganda }\end{array}$ & $(0,863)$ & $(0,355)$ & $-0,330$ & $-0,685$ & $30,65 \%$ & $0,67 \%$ & $31,32 \%$ \\
\hline Stres Kerja & $(0,773)$ & $(0,177)$ & $-0,091$ & $-0,268$ & $13,69 \%$ & $6,01 \%$ & $19,70 \%$ \\
\hline $\begin{array}{l}\text { Motivasi } \\
\text { Kerja }\end{array}$ & $\frac{0,861}{\text { Total }}$ & 0,307 & & 0,307 & $\begin{array}{r}26,42 \% \\
\mathbf{8 3 , 0 7 \%}\end{array}$ & $\frac{-}{7,44 \%}$ & $\begin{array}{r}26,42 \% \\
\mathbf{9 0 , 5 1 \%}\end{array}$ \\
\hline
\end{tabular}

Sumber : Smartpls 2.0 diolah tahun 2018

Hasil uji koefisien parameter antara Konflik Peran ganda terhadap Kinerja Perawat menunjukkan terdapat pengaruh langsung sebesar 30,65\%, sedangkan untuk pengaruh tidak langsung antara Konflik Peran ganda terhadap Kinerja Perawat melalui Stres Kerja maupun Motivasi Kerja mendapat nilai sebesar $0,67 \%$.

Konflik Peran Ganda berpengaruh secara langsung dan tidak langsung terhadap Kinerja perawat. Hasil uji koefisien parameter antara Konflik Peran ganda terhadap Kinerja Perawat menunjukkan terdapat pengaruh langsung sebesar 30,65\%, sedangkan untuk pengaruh tidak langsung antara Konflik Peran ganda terhadap Kinerja Perawat melalui Stres Kerja maupun Motivasi Kerja mendapat nilai sebesar 0,67\%.Stres Kerja berpengaruh secara langsung dan tidak langsung terhadap Kinerja Perawat.

Hasil uji koefisien parameter antara Stres Kerja terhadap Kinerja Perawat menunjukkan terdapat pengaruh langsung sebesar 13,69\%, sedangkan untuk pengaruh tidak langsung antara Stres Kerja terhadap Kinerja Perawat melalui Motivasi Kerja mendapat nilai sebesar 6,01\%. Motivasi Kerja berpengaruh secara langsung terhadap Kinerja Perawat.

Hasil uji koefisien parameter antara Motivasi kerja terhadap Kinerja
Perawat menunjukkan terdapat pengaruh langsung sebesar 26,42\%.nilai dari masing-masing pengaruh langsung variabel laten independen tersebut apabila secara bersama-sama menunjukkan kesesuaian dengan nilai $r$ square atau dengan kata lain hal ini juga dapat menyatakan bahwa variabel Beban Kerja, Konflik Peran ganda, stres kerja dan Motivasi Kerja mampu untuk menjelaskan variabel Kinerja Perawat sebesar $(12,31 \%+30,65 \%+13,69 \%+$ $26,42 \%)=83,07 \%$.

Cara perhitungan langsung dan tidak langsung Beban Kerja Terhadap Kinerja Perawat adalah dengan cara mengalihkan koefisien jalur (Path) dari beban kerja terhadap kinerja perawat dengan laten variabelnya, hal ini juga berlaku untuk melakukan perhitungan koefisien jalur variabel lainnya. Cara perhitungannya adalah :

Pengaruh Beban Kerja Terhadap Kinerja Perawat

$=L V C($ Beban Kerja $\rightarrow$ Kinerja $)$ x Direct

Path(Beban Kerja $\rightarrow$ Kinerja) x 100= $(0,732) \times(0,168) \times 100=12,31 \%$

Pengaruh Konflik Peran Ganda Terhadap Kinerja Perawat

$=L V C($ Konflik Peran Ganda $\rightarrow$ Kinerja $)$

x Direct Path(Konflik Peran Ganda $\rightarrow$ Kinerja) $\times 100=(0,863) \times(0,355) \times 100=$ $30,65 \%$

\section{Pengaruh Stres Kerja Terhadap Kinerja Perawat}


$=L V C($ Stres Kerja $\rightarrow$ Kinerja $) \times$ Direct

Path $($ Stres Kerja $\rightarrow$ Kinerja $)$ x $100=$ $(0,773) \times(0,177) \times 100=13,69 \%$

Pengaruh Motivasi Kerja Terhadap Kinerja Perawat

$=\operatorname{LVC}($ Motivasi Kerja $\rightarrow$ Kinerja $) \mathrm{x}$ Direct Path(Motivasi Kerja $\rightarrow$ Kinerja) $\mathrm{x}$ $100=(0,861) \times(0,307) \times 100=26,42 \%$

Sehingga dari setiap masingmasing pengaruh langsung variabel laten eksogen tersebut apabila secara bersamasama akan menunjukkan kesesuaian dengan $\mathrm{R}$ square atau dengan kata lain hal ini menyatakan bahwa variabel beban kerja, konflik peran ganda, stres kerja, motivasi kerja dan kinerja sebesar $(12,31 \%+30,65 \%+13,69 \%+26,42 \%)$ $=83,07 \%$.

Secara matematis, bentuk persamaan struktural dari model penelitian ini adalah sebagai berikut:

$$
\eta_{1}=\xi_{1} \cdot \gamma_{1}+\zeta_{1}
$$

Konflik Peran Ganda $=$ Beban Kerja x -0,697 + 0,515, Konflik Peran gandaPerawat di RSU Fastabiq Sehat PKU Muhamadiyah tahun 2018 dipengaruhi oleh beban Kerja sebesar 0,697 dan dipengaruhi oleh faktor lain sebesar 0,515.

$$
\eta_{2}=\xi_{1} \cdot \gamma_{2}+\eta_{1} \bullet \boldsymbol{\beta}_{1}+\zeta_{2}
$$

Stres Kerja $=$ Beban Kerja $\mathrm{x}$ 0,147 + Konflik Peran Ganda x 0,632+ 0,450, Stres Kerja Perawat di RSU Fastabiq Sehat PKU Muhamadiyah tahun 2018 dipengaruhi oleh beban kerja sebesar -0,147, konflik peran ganda sebesar 0,632 dan dipengaruhi oleh faktor lain sebesar 0,450.

$$
\eta_{3}=\xi_{1} \bullet \gamma_{3}+\eta_{1} \bullet \boldsymbol{\beta}_{2}+\eta_{2} \bullet \boldsymbol{\beta}_{4}+\zeta_{3}
$$

Motivasi Kerja $=$ Beban Kerja $\mathrm{x}$ 0,153 + Konflik Peran Ganda x -0,524 + Stres Kerja x -0,296 + 0,223, Motivasi Kerja perawat di RSU Fastabiq Sehat PKU Muhamadiyah tahun 2018 dipengaruhi oleh Beban Kerja sebesar 0,153, Konflik Peran Ganda sebesar 0,524,Stres Kerja sebesar -0,296, dan dipengaruhi oleh faktor lain sebesar 0,223 .

$$
\begin{gathered}
\eta_{4}=\xi_{1} \bullet \gamma_{4}+\eta_{1} \bullet \boldsymbol{\beta}_{3}+\eta_{2} \bullet \boldsymbol{\beta}_{5}+\eta_{3} \bullet \boldsymbol{\beta}_{6} \\
+\zeta_{4}
\end{gathered}
$$

Kinerja Perawat $=$ Beban Kerja $\times$ 0,168 + Konflik Peran Ganda x -0,355 + Stres Kerja $\mathrm{x}-0,177$ + Motivasi Kerja x 0,307 + 0,169, Kinerja Perawat di RSU Fastabiq Sehat PKU Muhamadiyah tahun 2018 dipengaruhi oleh Beban Kerja sebesar 0,168, Konflik Peran Ganda sebesar -0,355,Stres Kerja sebesar 0,177, Motivasi Kerja sebesar 0,307, dan dipengaruhi oleh faktor lain sebesar 0,169 .

Uji $Q$-Square $\left(Q^{2}\right)$ bertujuan untuk menilai besaran keragaman data atau variasi data penelitian terhadap fenomena yang sedang diteliti. Formula yang digunakan untuk mengukur $Q$-Square $\left(Q^{2}\right)$ adalah sebagai berikut:

$$
\begin{aligned}
Q^{2} & =1-\left(1-\mathrm{R}_{1}^{2}\right)\left(1-\mathrm{R}_{2}^{2}\right)\left(1-\mathrm{R}_{3}^{2}\right)\left(1-\mathrm{R}_{4}^{2}\right) \\
Q^{2} & =1-((1-0,485137) \times(1-0,550435) \\
& \mathrm{x}(1-0,776768) \times(1-0,830679)) \\
Q^{2}= & 0,9913 \Rightarrow 99,13 \% . \\
& \text { Berdasarkan hasil perhitungan }
\end{aligned}
$$
tersebut dapat disimpulkan bahwa model mampu menjelaskan variabilitas data sebesar 99,13\%, sedangkan 0,87 \% dijelaskan oleh variabel lain yang tidak dikaji dalam penelitian ini.

\section{Pembahasan \\ Pengaruh Beban Kerja Terhadap Kinerja Perawat}

Beban Kerja berpengaruh positif terhadap Kinerja Perawat, hasil uji menunjukkan ada pengaruh langsung sebesar 0,168 , sedangkan nilait-statistic sebesar 2,12dan signifikan pada $\alpha=5 \%$. Nilai $t$-statistic tersebut berada di atas nilai kritis (1,96). Beban Kerja berpengaruh secara langsung dan tidak langsung terhadap Kinerja Perawat.

Hasil uji koefisien parameter antara Beban Kerja terhadap Kinerja Perawat menunjukkan terdapat pengaruh langsung sebesar 12,31\%, sedangkan untuk pengaruh tidak langsung antara Beban Kerja terhadap Kinerja Perawat melalui Konflik Peran Ganda, Stres Kerja, maupun Motivasi Kerja mendapat nilai sebesar $0,76 \%$.Kinerja Perawat di 
RSU Fastabiq Sehat PKU Muhamadiyah tahun 2018 dipengaruhi oleh Beban Kerja sebesar 0,153, artinya terdapat pengaruh positif dari Beban Kerja terhadap Kinerja Perawat, semakin rendah beban kerja maka akan semakin tinggi pula Kinerja perawat di RSU Fastabiq Sehat PKU Muhamadiyah tahun 2018.

Beban kerja sangat penting bagi sebuah perusahaan. Dengan pemberian beban kerja yang efektif perusahaan dapat mengetahui sejauh mana karyawannya dapat diberikan beban kerja yang maksimal dan sejauh mana pengaruhnya terhadap kinerja perusahaan itu sendiri.

Hasil analisis menunjukan bahwa variabel beban kerja memiliki korelasi dengan variabel kinerja dan beban kerja berpengaruh positif dan signifikan secara langsung terhadap kinerja karyawan. Maka adanya penerapanbeban kerja membuat karyawan dituntut untuk mengeluarkan seluruh potensi yang dimiliki. ${ }^{17}$

Beban kerja sangat berpengaruh terhadap kinerja seseorang dalam melakukan pekerjaaannya. Pekerja yang mempunyai suatu beban kerja berlebih akan menurunkan kualitas hasil kerja dan memungkinkan adanya inefisiensi waktu dan begitupun sebaliknya pekerjaan yang dijalani dapat menjadi motivasi pekerja untuk lebih giat mencapai suatu hasil yang akan diraihnya. Beban kerja tidak hanya dipandang sebagai beban kerja fisik akan tetapi sebagai beban kerja mental.

Program kerja yang memungkinkan karyawan menikmati akhir pekan yang panjang sepanjang tahun, dimaksud sebagai insentif dengan keyakinan sistem ini akan mengarah pada peningkatan produktivitas.

Karyawan akan memperoleh manfaat dengan adanya waktu senggang yang bertambah dan mendapatkan kebebasan lebih untuk mengurus urusan pribadi, kehidupan keluarga, dan menambah pendidikan. ${ }^{18}$
Melalui telaah jurnal mengenai beban kerja terhadap kinerja perawat di RSU Fastabiq Sehat PKU Muhamadiyah, didapatkan $p$-value $=0,027 ; \quad \mathrm{OR}=$ 5,$539 ; 95 \%$ CI $(2,112-9,434)$. Hasil penelitian ini menyatakan beban kerja berpengaruh signifikan secara parsial terhadap kinerja perawat di RSU Fastabiq Sehat PKU Muhamadiyah.

Menurut asumsi peneliti, bahwa beban kerjajumlah pekerjaan dan banyaknya jenis pekerjaan yang harus diselesaikan perawat dalam jangka waktu tertentu.

Beban kerja sangat berpengaruh terhadap kinerja seseorang dalam melakukan pekerjaaannya dimana Tingkat beban kerja diperhitungkan dari jumlah waktu yang telah dipakai untuk mengerjakan suatu tugas atau pekerjaannya sampai selesai.

\section{Pengaruh Konflik Peran Ganda Terhadap Kinerja Perawat}

Konflik Peran ganda berpengaruh negatif terhadap Kinerja Perawat, hasil uji menunjukkan ada pengaruh sebesar 0,355 , sedangkan nilai $t$-statistic sebesar 4,53 dan signifikan pada $\alpha=5 \%$. Nilai $t$ statistic tersebut berada di atas nilai kritis $(1,96)$. Konflik Peran Ganda berpengaruh secara langsung dan tidak langsung terhadap Kinerja perawat.

Hasil uji koefisien parameter antara konflik peran ganda terhadap kinerja perawat menunjukkan terdapat pengaruh langsung sebesar 30,65\%, sedangkan untuk pengaruh tidak langsung antara konflik peran ganda terhadap kinerja perawat melalui Stres Kerja maupun motivasi kerja mendapat nilai sebesar $0,67 \%$.

Kinerja Perawat di RSU Fastabiq Sehat PKU Muhamadiyah tahun 2018 dipengaruhi oleh konflik peran ganda sebesar 0,697 , artinya terdapat pengaruh yang negatif dari konflik peran ganda terhadap kinerja perawat, semakin tinggi beban kerja maka akan semakin rendah kinerja perawat di RSU Fastabiq Sehat PKU Muhamadiyah tahun 2018. 
Konflik peran adalah dimana adanya ketidakcocokan antara harapanharapan yang berkaitan dengan suatu peran dimana dalam kondisi yang cukup ekstrem kehadiran atau lebih harapan peran.konflik peran ganda adalah salah satu bentuk konflik antar peran yang diakibatkan pekerjaan dan keluarga saling tidak cocok satu sama lain, kewajiban pekerjaan yang mengganggu kehidupan rumah tangga, permintaan, waktu dan ketegangan dalam keluarga yang disebabkan harapan dari dua peran yang berbeda.

Konflik peran ganda muncul antara harapan dari dua peran yang berbeda yang dimiliki oleh seseorang. Di pekerjaan, seorang wanita yang profesional diharapkan untuk agresif, kompetitif, dan dapat menjalankan komitmennya pada pekerjaan. Di rumah, wanita sering kali diharapkan untuk merawat anak, menyayangi dan menjaga suaminya. ${ }^{19}$

Konflik peran ganda dapat menurunkan kinerja karyawan, sementara menurunnya kinerja karyawan bisa memberi dampak pada meningkatnya keinginan untuk keluar, meningkatnya absensi, dan menurunya komitmen organisasi Jadi hal ini merupakan keadaan yang berbahaya bagi organisasi, karena bisa menyebabkan pelaksanaan pekerjaan terganggu, yang akhirnya bisa menurunya kinerja organisasi. ini merupakan salah satu hal yang harus diperhatikan perusahaan dalam mengolah Sumber Daya Manusia untuk dapat meningkatkan efisiensi dan efektivitas kerja. $^{20}$

Melalui telaah jurnal pengaruh konflik peran ganda, dukungan sosial dan stres kerja terhadap kinerja perawat, didapatkan : $p$-value $=0,002 ; \mathrm{OR}=$ 9,$346 ; 95 \%$ CI $(6,205-14,413)$, hasil penelitian ini menyatakan bahwa konflik pekerjaan-keluarga berpengaruh signifikan terhadap terjadinya Kinerja perawat wanita rumah sakit yang mana bahwa apabila semakin rendah resiko untuk terjadi konflik pekerjaan-keluarga yang dialami maka akan meningkatkan kinerja perawat wanita rumah sakit.

Menurut asumsi peneliti, konflik kerja adalah kondisi pertentangan yang rentan terjadi pada perawat akibat adanya tidaksesuaian harapan dan tuntutan kerja dengan tugas sebagai ibu rumah tanggayang dapat mengganggu pencapaian tujuan pekerjaannya. Indikatornya adalah konflik intrapersonal,konflik interpersonal dan konflik individu dengan organisasi

\section{Pengaruh Stres Kerja Terhadap Kinerja Perawat}

Stres Kerja berpengaruh negatif terhadap Kinerja Perawat, hasil uji menunjukkan ada pengaruh sebesar 0,177 , sedangkan nilai $t$-statistic sebesar 4,93dan signifikan pada $\alpha=5 \%$. Nilai $t$ statistic tersebut berada di atas nilai kritis $(1,96)$. Stres Kerja berpengaruh secara langsung dan tidak langsung terhadap Kinerja perawat.

Hasil uji koefisien parameter antara Stres Kerja terhadap kinerja perawat menunjukkan terdapat pengaruh langsung sebesar 13,69\%, sedangkan untuk pengaruh tidak langsung antara Stres Kerja terhadap kinerja perawat melalui Komitmen mendapat nilai sebesar $6,01 \%$.

Kinerja perawat di RSU Fastabiq Sehat PKU Muhamadiyah tahun 2018 dipengaruhi oleh Stres Kerja sebesar 0,177 , artinya terdapat pengaruh yang negatif dari Stres Kerja terhadap kinerja perawat, semakin tinggi Stres Kerja yang dialami oleh perawatmaka akan semakin rendah kinerja perawat di RSU Fastabiq Sehat PKU Muhamadiyah tahun 2018.

Stres merupakan kondisi ketegangan yang berpengaruh terhadap emosi, jalan pikiran dan kondisi fisik seseorang. Stres yang tidak diatasi dengan baik biasanya akan berakibat pada ketidak mampuan seseorang berinteraksi secara positif dengan lingkungannya, baik dalam arti lingkungan pekerjaan maupun diluarnya. 
Timbulnya stres kerja pada seseorang tenaga kerja dapat melalui tiga tahap, yaitu tahap pertama yaitu reaksi awal yang merupakan fase inisial dengan timbulnya beberapa gejala atau tanda, namun masih dapat diatasi oleh mekanisme pertahanan diri. ${ }^{21}$

Sumber stres kerja menyebabkan seseorang tidak berfungsi optimal maupun jatuh sakit, tidak hanya datang dari satu macam pembangkit tetapi juga dari satu macam pembangkit tetapi juga dari beberapa pembangkit stres.

Sebagian dari waktu adalah untuk bekerja, karena itu lingkungan pekerjaan mempunyai pengaruh besar terhadap kesehatan seorang pekerja. Pembangkit stres di pekerjaan merupakan pembangkit stres yang besar terhadap jatuh sakitnya seorang pekerja. ${ }^{22}$

Melalui telaah jurnal mengenai pengaruh beban kerja dan stres kerja terhadap kinerja perawat di RSU Melati Perbaungan, didapatkan P-value $=0,016$; $\mathrm{OR}=6,024 ; 95 \%$ CI $(3,332-12,121)$. hasil penelitian ini menyatakan bahwa semakin rendah stres kerja yang dialami oleh perawat maka akan meningkatkan kinerja perawat pada saat melakukan tindakan kepasien.

Menurut asumsi peneliti, bahwa stres kerja adalah kondisi ketegangan yang ditunjukan perawat sebagai respon akibat adanya perubahan lingkungan kerja dan bersifat mengganggu dalam melaksanakan tugas pekerjaan bahkan jika tingkat stres yang dialami oleh perawat yang tidak tertangani akan mempengaruhi kinerjanya dalam memberikan pelayanan.

\section{Pengaruh Motivasi Kerja Terhadap Kinerja Perawat}

Motivasi Kerja berpengaruh positif terhadap Kinerja Perawat, hasil uji menunjukkan ada pengaruh positif 0,307 , sedangkan nilai $T$-Statistic sebesar 2,65 dan signifikan pada $\alpha=5 \%$. Nilai $T$ Statistic tersebut berada di atas nilai kritis $(1,96)$.Motivasi kerja berpengaruh secara langsung terhadap kinerja perawat.
Hasil uji koefisien parameter antara motivasi kerja terhadap kinerja perawat menunjukkan terdapat pengaruh langsung sebesar 26,42\%. Kinerja perawat di RSU Fastabiq Sehat PKU Muhamadiyah tahun 2018 dipengaruhi oleh motivasi kerja sebesar 0,307 , artinya terdapat pengaruh yang positif dari motivasi kerja terhadap kinerja perawat, semakin tinggi motivasi perawat maka akan semakin tinggi kinerja perawat di RSU Fastabiq Sehat PKU Muhamadiyah tahun 2018.

Motivasi (motivation) adalah keinginan dalam diri seseorang yang menyebabkan orang tersebut bertindak. Seseorang biasanya bertindak karena satu alasan yaitu untuk mencapai tujuan. Jadi, motivasi adalah sebuah dorongan yang diatur oleh tujuan dan jarang muncul dalam kekosongan. motivasi juga merupakan keinginan yang terdapat pada seseorang individu yang merangsangnya untuk melakukan tindakan-tindakan. ${ }^{23}$

Motivasi kerja adalah suatu kondisi yang berpengaruh untuk membangkitkan, mengarahkan dan memelihara perilaku yangberhubungan dengan lingkungan kerja.motivasi berfokus pada faktor-faktor dalam diri seseorang yang mendorong, mengarahkan, mempertahankan dan juga menghentikan perilaku. Sedangkan teori proses dari motivasi berkenaan dengan bagaimana prilaku individu didorong, diarahkan, dipelihara ataupun diberhentikan. ${ }^{24}$

Melalui telaah jurnal mengenai pengaruh disiplin kerja dan motivasi berka terhadap kinerja karyawan pada rumah sakit umum daerah kanjuruhan malang didapatkan $\mathrm{P}$-value $=0,042 ; \mathrm{OR}=$ 3,$245 ; 95 \%$ CI $(1,423-5,101)$. hasil penelitian ini menyatakan bahwa motivasi kerja berpengaruh terhadap kinerja perawat dimana dalam hal ini pengurus ataupun pimpinan instansi sering memberikan bonus/reward pada karyawan yang mencapai target atau berprestasi sehingga termotivasi perawat untuk bekerja lebih menjadi meningkat. 
Menurut asumsi peneliti, bahwa motivasi kerja merupakan dorongan ataupun kekuatan diri individu itu sendiri baik dari dalam maupun dari luar untuk merespon dan melaksanakan tugas pekerjaannya terutama dalam mencapai suatu tujuan organisasi.

\section{Kesimpulan}

Berdasarkan temuan tersebut dapat ditarik kesimpulan bahwa dimana variabel Kinerja Perawat wanita di Ruang Rawat Inap RSU Fastabiq Sehat PKU Muhamadiyah dipengaruhi oleh beban kerja (12,31\%), Konflik Peran ganda $(30,65 \%)$, stres kerja $(13,69 \%)$ dan motivasi kerja (26,42\%). pengaruh langsung Kinerja Perawat wanita di Ruang Rawat Inap RSU Fastabiq Sehat PKU Muhamadiyah sebesar 83,07\% dan pengaruh tidak langsung sebesar 7,44\%. Total pengaruh langsung dan tidak langsung kinerja perawat wanita sebesar $90,51 \%$.

Berdasarkan hal tersebut maka dapat dinyatakan bahwa konflik peran ganda merupakan faktor paling dominan yang sangat mempengaruhi kinerja perawat wanita di ruang rawat inap RSU Fastabiq Sehat PKU Muhamadiyah dimana perawat wanita yang telah menikah dan juga bekerja dimana perawat wanita beresiko kecil kemungkinan untuk mengalami konflik ditempat kerja ataupun mengalami konflik dirumah.

\section{Saran}

Perawat RSU Fastabiq Sehat PKU Muhamadiyah untuk dapat selalu menciptakan ataupun menjaga kondisi kerja yang nyaman sehingga dapat menghindari untuk terjadinya konflik dalam bekerja.

\section{Daftar Pustaka}

[1] Pieter, H.Z. \& Lubis, N.L. Pengantar Psikologi Dalam Keperawatan. Jakarta: Kencana; 2010.
[2] Nursalam. Proses dan Dokumentasi Keperawatan, Konsep dan Prakti. Jakarta: Salemba Medika; 2009.

[3] Triyanto. Jurnal keperawatan soedirman (the soedirman journal of nursing),

2http://jurnalonline.unsoed.ac.id/ind ex.php/keperawatan/article/viewFile 2294/136; 2008.

[4] Setiyawan, Budi dan Waridin. Pengaruh Disiplin Kerja Karyawan Dan Budaya Organisasi Terhadap Kinerja Di Divisi Radiologi RSUP Dokter Kariadi Semarang. JRBI. Vol 2. No 2; 2006.

[5] Sedarmayanti. Sumber Daya Manusia dan Produktivitas Kerja, Bandung : Mandar Maju; 2007.

[6] Arinta, Imelda L. \& Saifuddin Azwar. Peran Jenis Androgini dan Konflik Peran-Ganda pada Ibu Bekerja. Bandung: Jurnal Psikologi; 2007.

[7] Davis, M. Eshelman, R.E. dan Mckay,M. Panduan Relaksasi dan Reduksi Stres. Edisi ketiga (terjemahan Hamid dan Keliat). Jakarta: EGC; 2010.

[8] Prihatini, L. DAnalisis hubungan Beban Kerja dengan Stress Kerja Perawat di Tiap Ruang Rawat Inap RSUD Sidikalang. Tesis. Sumatera Utara : Fakultas Ilmu Kesehatan Universitas Sumatera Utara; 2007.

[9] Ari Setiawan \& Saryono. Metodologi Penelitian Kebidanan. yogjakarta : Nuha Medika; 2010.

[10] Notoadmojo, Soekidjo. Metodologi Penelitian Kesehatan. Jakarta : Rineka Cipta; 2010.

[11] Ghozali, Imam. Metode Alternatif Partial Least Square PLS. Semarang : Badan Penerbit Undip. 2013.

[12] Supartopel, Adikoesoemo. Manajemen Rumah Sakit. Jakarta : PT. Pusaka Sinar Harapan; 2008.

[13] Ghozali I. Structural Equation Modelling teori konsep dan aplikasi dengan program LISREL 8.80. Edisi 2. Semarang : Badan Penerbit Universitas Diponegoro; 2008. 
[14] Sugiyono. Metode Penelitian Kuantitatif dan Kualitatif dan $R$ \& D. Cetakan Ke 7. Bandung : CV Alfabeta; 2009.

[15] Ferdinand, A. Structural Equation Modelling Dalam Penelitian Manajemen. Semarang : Fakultas Ekonomi Universitas Diponegoro; 2012.

[16] Marquis, B. L., \& Huston Kepemimpinan dan Manajemen Keperawatan. Teori \& Aplikasi. Edisi 4. Jakarta: EGC; 2010.

[17] Yudha Adityawarman, "Pengaruh Beban Kerja terhadap Kinerja Karyawan PT. Bank Rakyat Indonesia (persero) Tbk Cabang Krekot".Jurnal Manajemen dan Organisasi, volume 6 nomor 1 ; 2015.

[18] Indriyani, Azazah. Tesis. Pengaruh konflik peran ganda, dukungan sosial dan stres kerja terhadap kinerja perawat wanita Rumah Sakit Roemani

Muhammadiyah

Semarang. Semarang; 2012.

[19] Tampubolon, Manahan P. Perilaku Keorganisasian. Bogor: Ghalia Indonesia; 2010.

[20] Suprihanto, John Perilaku Organisasi. Jakarta : Lembaga FEUI; 2007.

[21] Siagian, Sondang P. Kiat Meningkatkan Produktivitas Kerja. Jakarta : PT Rineka Cipta; 2009.

[22] Munandar, A. S. Psikologi industri dan organisasi. Jakarta : UI Press; 2006.

[23] Mathis, R dan Jackson, WHuman Resources Development (Track MBA series/terjemahan). Jakarta; Prestasi Pustaka; 2006.

[24] Mangkunegara, AP. Manajemen Sumber Daya manusia Strategik, Edisi Ketiga. Jakarta : Ghalia Indonesia; 2013 